\title{
DYSLIPIDEMIA IS A PREDICTIVE RISK FACTOR FOR CORONARY HEART DISEASES (CHD) IN YOUNG, OBESE AND NON-VEGETERIAN JUNK FOOD EATERS, A STUDY CONDUCTED IN B.S. MEDICAL COLLEGE, BANKURA, WEST BENGAL
}

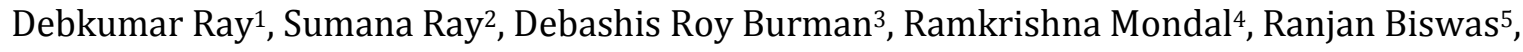
Phalguni Chakrabarti6, Tapan Kumar Jana ${ }^{7}$.

1. Assistant Professor, Department Of Biochemistry, B.S.Medical College,Bankura, West Bengal.

2. Research Fellow, Department Of Biochemistry, Burdwan University , West Bengal.

3. Assistant Professor, Department Of Oncopathology, Calcutta Medical College, Kolkata.

4. Associate Professor, Department Of Surgery, B.S.Medical College,Bankura, West Bengal.

5. RMO cum Clinical Tutor, Department of Psychiartry, B.S.Medical College,Bankura, West Bengal.

6. Assistant Professor, Department Of Biochemistry, B.S.Medical College, Bankura, West Bengal.

7. Associate Professor, Department of Anatomy, NBMC, Darjeeling, West Bengal.

\section{CORRESPONDING AUTHOR:}

Debkumar Ray,

KL-1, Jagatpur Ganga Yamuna Aptt,

Block-B,Flat No: C \& D,

Kolkata-700059.

Email: dr.debkumar@gmail.com

\section{HOW TO CITE THIS ARTICLE:}

Debkumar Ray, Sumana Ray, Debasish Ray Burman, Ramkrishna Mondal, Ranjan Biswas, Phalguni Chakrabarti, Tapan Kumar Jana. "Dyslipidemia is a Predictive Risk Factor for Coronary Heart Diseases (CHD) in young, obese and non- vegeterian junk food eaters, astudy conducted in B.S. Medical College, Bankura, West Bengal". Journal of Evolution of Medical and Dental Sciences 2013; Vol2, Issue 24, June 17; Page: 4446-4454.

ABSTRACT: A randomized study was conducted among young,obese,non-vegeterian junk food eaters in semi-urban populations and it has been established that the measurement of BMI (Body Mass Index) along with estimation of lipid profile and fasting blood sugar at least once in a year for young obese non-vegeterian, regular junk food eaters may prevent CHD by suitable preventive measure at the earliest.

Coronary Heart Diseases (CHD) has become an ubiquitous cause of morbidity and a leading contributor to mortality in most countries. ${ }^{12}$ The rise and recent decline of the CHD epidemic in the developed countries have been well documented. ${ }^{3} 4$ The emergence of the CHD epidemic in the developing countries during the past two to three decades has attracted less comment and little public health response, even within these countries. It is not widely realized that at present, the developing countries contribute a greater share to the global burden of CHD than the developed countries. $^{4}$ It has been estimated that 5.3 million deaths attributable to CHD occurred in the developed countries in 1990, whereas the corresponding figure for the developing countries ranged between 8 to 9 million.A second cause for considerable alarm is the projected rise in both proportional and absolute CHD mortality rates in the developing countries over the next 25 years. ${ }^{6}$ The reasons for this anticipated acceleration of the epidemic are many. In the second half of the twentieth century, most developing countries experienced a major surge in life expectancy. ${ }^{8}$ For 
example, the life expectancy in India rose from 41.2 years in 1951-1961 to 61.4 years in 1991-1996. This was principally due to a decline in deaths occurring in infancy, childhood, and adolescence and was related to more effective public health responses to perinatal, infectious, and nutritional deficiency disorders and to improved economic indicators such as per-capita income and social indicators such as female literacy in some areas. A third reason to arouse concern is that if population levels of CHD risk factors rise as a consequence of adverse lifestyle changes accompanying industrialization and urbanization, the rates of CHD mortality and morbidity could rise even higher than the rates predicted solely by demographic changes. Both the degree and the duration of exposure to CHD risk factors would increase due to higher risk factor levels coupled with a longer life expectancy. An increase in body weight (adjusted for height), blood pressure, and cholesterol levels and the substantially higher levels of CHD risk factors in urban population groups compared with rural population groups in India provide evidence of such trends. ${ }^{9} 10$ A crosssectional survey of urban Delhi and its rural environs revealed that a higher prevalence of coronary heart disease (CHD) in the urban sample was associated with higher levels of body mass index, blood pressure, fasting blood lipids (total cholesterol, ratio of cholesterol to HDL cholesterol, triglycerides), and diabetes. ${ }^{9}$ As recently reviewed by Drewnowski and Popkin, ${ }^{13}$ the global availability of cheap vegetable oils and fats has resulted in greatly increased fat consumption among low-income countries. The transition now occurs at lower levels of the gross national product than previously and is further accelerated by rapid urbanization.The upper-income persons who were consuming a relatively high-fat diet ( $>30 \%$ of daily energy intake) rose from $22.8 \%$ to $66.6 \%$ between 1989 and 1993. The lower- and middle-income classes also showed a rise (from $19 \%$ to $36.4 \%$ in the former and from $19.1 \%$ to $51.0 \%$ in the latter). ${ }^{11}$ The Asian countries, with a diet that is traditionally high in carbohydrates and low in fat, have shown an overall decline in the proportion of energy from complex carbohydrates along with the increase in the proportion of fat. The globalization of food production and marketing is also contributing to the increasing consumption of energy-dense foods poor in dietary fiber and several micronutrients. ${ }^{14}$

Obesity is now recognized as the most prevalent metabolic disease world-wide, reaching epidemic proportions in both developed and developing countries and affecting not only adults but also children and adolescents. The WHO has already declared obesity a global epidemic that constitutes one of the biggest current health problems 15.

Overweight and obesity are responsible for about $80 \%$ of cases of type 2 diabetes, $35 \%$ of ischemic heart disease and $55 \%$ of hypertensive disease among adults ${ }^{16}$.

Obesity is a chronic disease characterised by an increase of body fat stores. In clinical practice, the body fatness is assessed by the body mass index (BMI). BMI is calculated as measured body weight $(\mathrm{kg})$ divided by measured height squared $(\mathrm{m} 2)$.

In adults (age over 18 years) obesity is defined by a BMI $\geq 30 \mathrm{~kg} / \mathrm{m} 2$ and overweight (also termed pre-obesity) by a BMI between 25 and $29.9 \mathrm{~kg} / \mathrm{m} 2$. Many people in the overweight range of BMI 25$29.9 \mathrm{~kg} / \mathrm{m} 2$ will become obese in their lifetime ${ }^{15,17}$ 


\section{ORGINAL ARTICLE}

Table 1. BMI categories(WHO 1997) ( kg/m2)

\begin{tabular}{|l|}
\hline Underweight $<18.5$ \\
\hline Healthy weight $18.5-24.9$ \\
\hline Pre-obese state $25.0-29.9$ \\
\hline Obesity grade I $30.0-34.9$ \\
\hline Obesity grade II $35.0-39.9$ \\
\hline Obesity grade III $\geq 40$ \\
\hline
\end{tabular}

The cause of obesity is complex and multi-factorial 18,19

High energy density diet commonly junk food, increased portion size, low physical activity and adoption of a sedentary lifestyle as well as eating disorders are considered as important risk factors for the development of obesity 17,20 .

Junk food is an informal term for food that is of little nutritional value and often high in fat, sugar, and calories. Junk foods typically contain high levels of calories from sugar or fat with little protein, vitamins or minerals. Common junk foods include salted snack foods, gum, candy, sweet desserts, fried fast food, and carbonated beverages. ${ }^{21}$

A study by Paul Johnson and Paul Kenny at the Scripps Research Institute (2008) suggested that junk food consumption alters brain activity in a manner similar to addictive drugs like cocaine or heroin. ${ }^{22}$ After many weeks with unlimited access to junk food, the pleasure centers of rat brains became desensitized, requiring more food for pleasure. After the junk food was taken away and replaced with ahealthy diet, the rats starved for two weeks instead of eating nutritious fare. ${ }^{23}$ A 2007 British Journal of Nutrition study found that female rats who eat junk food during pregnancy increased the likelihood of unhealthy eating habits in their offspring. ${ }^{22}$

A report published in the Journal of the Federation of American Societies for Experimental Biology suggests that babies of mothers with a high-sugar and high-fat diet while pregnant are more prone to junk food themselves. The study was conducted on rats and suggests that "infants whose mothers eat excessive amounts of high-fat, high-sugar junk foods when pregnant or breastfeeding are likely to have a greater preference for these foods later in life." 24

Junk food is a derisive slang term for food that is of little nutritional value and often high in fat, sugar, salt, and calories ${ }^{252627}$ It is widely believed that the term was coined by Michael Jacobson, director of the Center for Science in the Public Interest, in 1972.28 Junk foods typically contain high levels of calories from sugar or fat with little protein, vitamins or minerals. Foods commonly considered junk foods include salted snack foods, gum, candy, sweet desserts, fried fast food, and sugary carbonated beverages. ${ }^{29}$ Many foods such as hamburgers, pizza, and tacos can be considered either healthy or junk food depending on their ingredients and preparation methods with the more highly processed items usually falling under the junk food category. ${ }^{30}$ What is and is not junk food can also depend on the person's class and social status, with wealthier people tending to have a 
broader definition while lower-income consumers may see fewer foods as junk food, especially certain ethnic foods.

Despite being labeled as "junk" consuming such foods usually does not pose any immediate health concerns and is generally safe when integrated into a well balanced diet. 3132

Seventy nine cases have been taken at random where the male female ratio was 1:1 with the age group 25to 45 years. At the time of selection of the study group $(n=42)$ the individual was evaluated on the basis of family history of CHD, regular food habit with type of junk food consumption, history of smoking, pattern of life style, measurement of height and weight . Total number of cases in control group $(n=37)$ was evaluated on the same criteria. Serum total cholesterol,triglyceride,HDL-C,LDL-C was estimated by enzymatic method and fasting blood sugar by glucose oxidase and peroxidase method and expressed in terms of mg/dl. Body mass index (BMI) was calculated by weight in kilogram devided by height in squere meter.

Table:2 Inclusion criteria for the selection of Study group

\begin{tabular}{|c|l|}
\hline & Study Group(n=42) \\
\hline 1. & Elevated Cholesterol \\
\hline 2. & Elevated Triglyceride \\
\hline 3. & Decreased HDL \\
\hline 4. & Normal or elevated blood sugar \\
\hline 5. & Sedentary life style \\
\hline 6. & Family history of CHD \\
\hline 7. & Regular intake of junk food \\
\hline 8. & Young and Obese with high BMI \\
\hline 9. & Smoking habit \\
\hline
\end{tabular}

RESULTS TABLE: 3

\begin{tabular}{|l|l|l|}
\hline Parameters Studied & $\begin{array}{l}\text { Study Group (n=42) } \\
\text { Mean } \pm \text { SD }\end{array}$ & $\begin{array}{l}\text { Control Group (n=37) } \\
\text { Mean } \pm \text { SD }\end{array}$ \\
\hline $\begin{array}{l}\text { BMI(Body Mass Index) } \\
(\mathrm{kg} / \mathrm{m} 2)\end{array}$ & $26.98 \pm 4.17$ & $19.06 \pm 2.15$ \\
\hline $\begin{array}{l}\text { Total Cholesterol } \\
\text { (mg/dl) }\end{array}$ & $243.89 \pm 78.37$ & $142.35 \pm 27.49$ \\
\hline $\begin{array}{l}\text { Triglyceride } \\
\text { (mg/dl) }\end{array}$ & $174.97 \pm 99.31$ & $97.98 \pm 36.84$ \\
\hline $\begin{array}{l}\text { HDL Cholesterol } \\
\text { (mg/dl) }\end{array}$ & $32.74 \pm 8.21$ & $46.59 \pm 6.13$ \\
\hline $\begin{array}{l}\text { VLDL Cholesterol } \\
\text { (mg/dl) }\end{array}$ & $36.29 \pm 3.76$ & $18.21 \pm 9.12$ \\
\hline $\begin{array}{l}\text { LDL Cholesterol } \\
\text { (mg/dl) }\end{array}$ & $195.23 \pm 12.76$ & $76.54 \pm 9.52$ \\
\hline $\begin{array}{l}\text { Blood (Sugar Fasting) } \\
\text { (mg/dl) }\end{array}$ & $115.09 \pm 11.03$ & $114.06 \pm 25.04$ \\
\hline
\end{tabular}


Figure:1 Diagram represents BMI (Body Mass Index)(kg/sqm) in study(n=42) and control $(\mathrm{n}=37)$ group

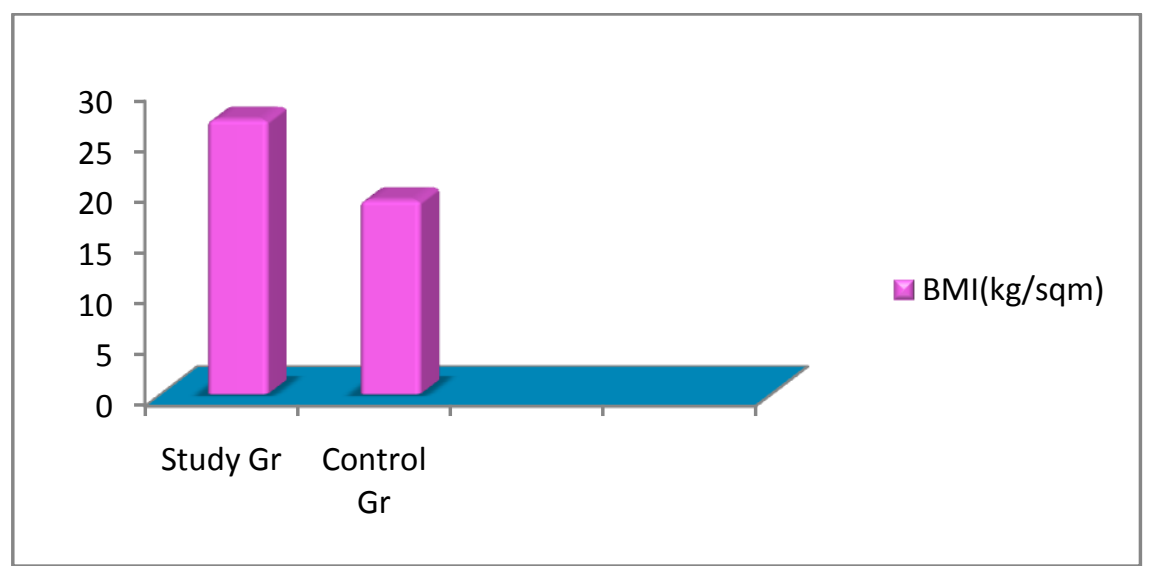

Figure:2 Diagram represents Total Cholesterol $(\mathrm{mg} / \mathrm{dl})$ in study $(\mathrm{n}=42)$ and control $(\mathrm{n}=37)$ group

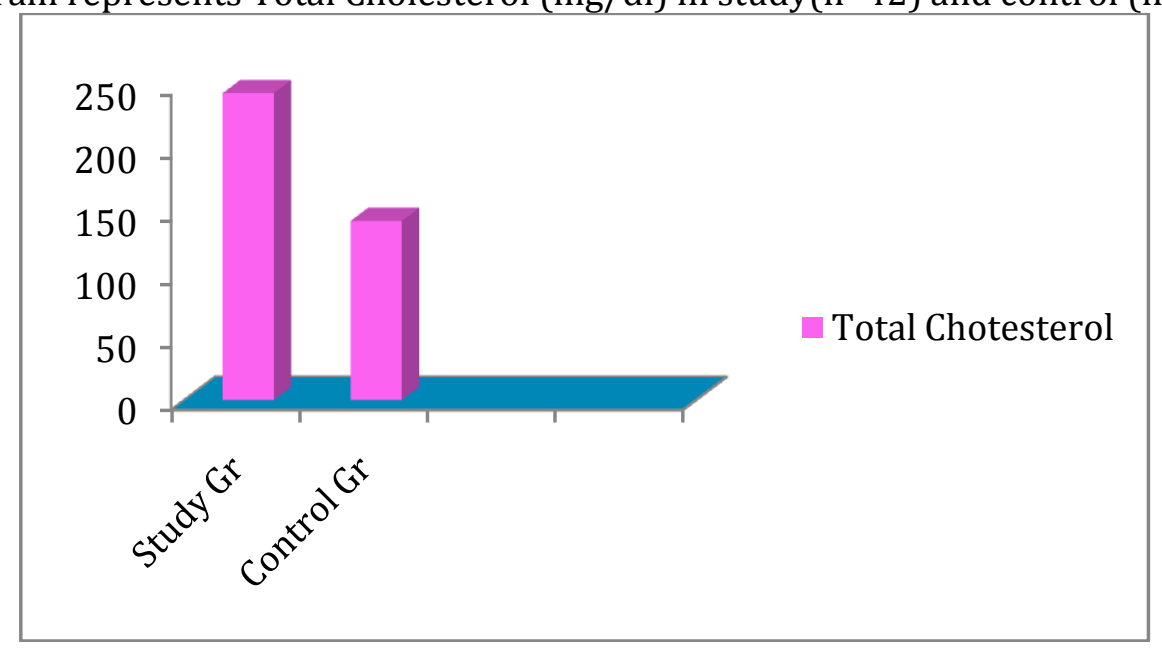

Figure:3 Diagram represents Triglyceride(TGL) $(\mathrm{mg} / \mathrm{dl})$ in study $(\mathrm{n}=42)$ and control $(\mathrm{n}=37)$ group

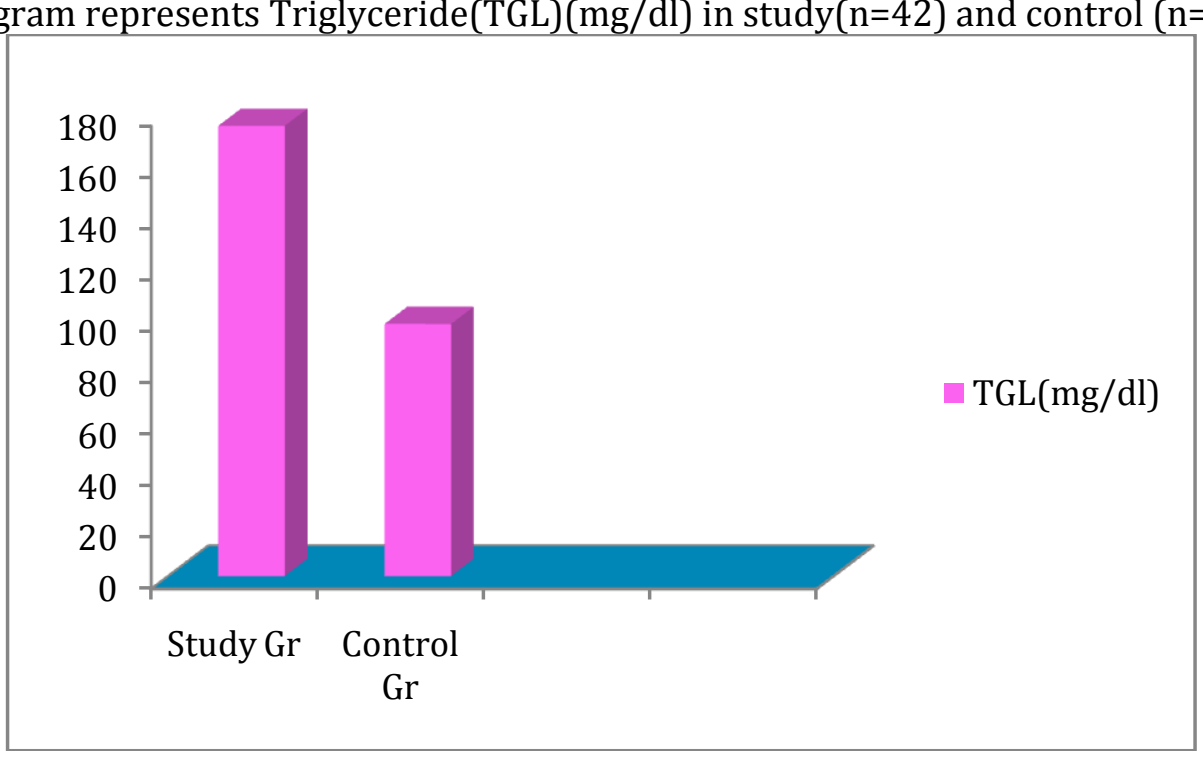




\section{ORGINAL ARTICLE}

Figure:4 Diagram represents HDL-C(mg/dl) in study $(n=42)$ and control $(n=37)$ group

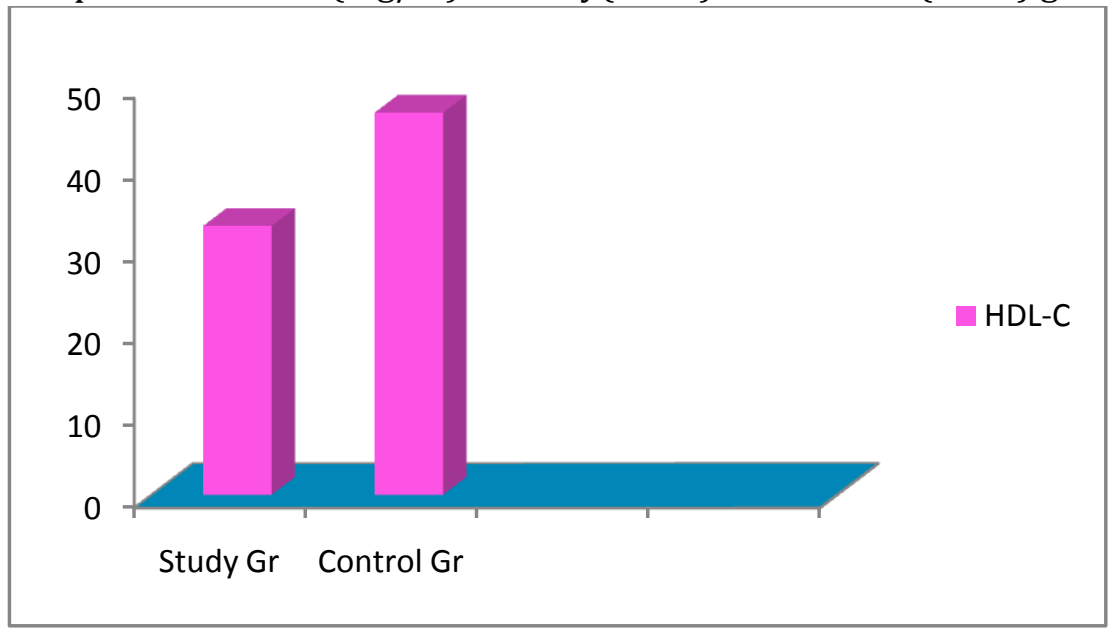

Figure:5 Diagram represents VLDL-C $(\mathrm{mg} / \mathrm{dl})$ in study(n=42) and control $(\mathrm{n}=37)$ group

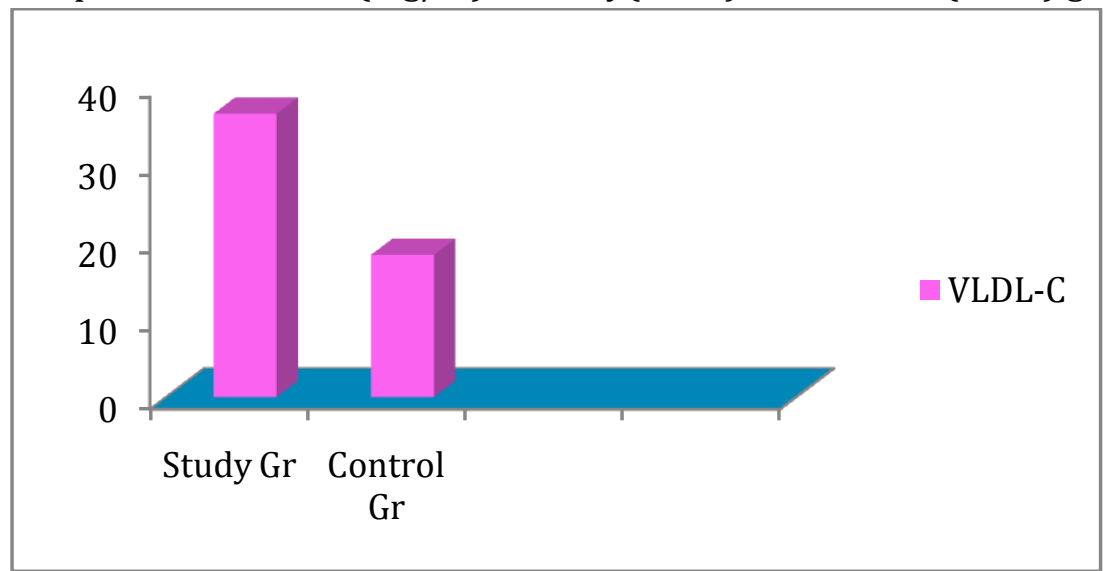

Figure:6 Diagram represents LDL-C(mg/dl) in study $(\mathrm{n}=42)$ and control $(\mathrm{n}=37)$ group

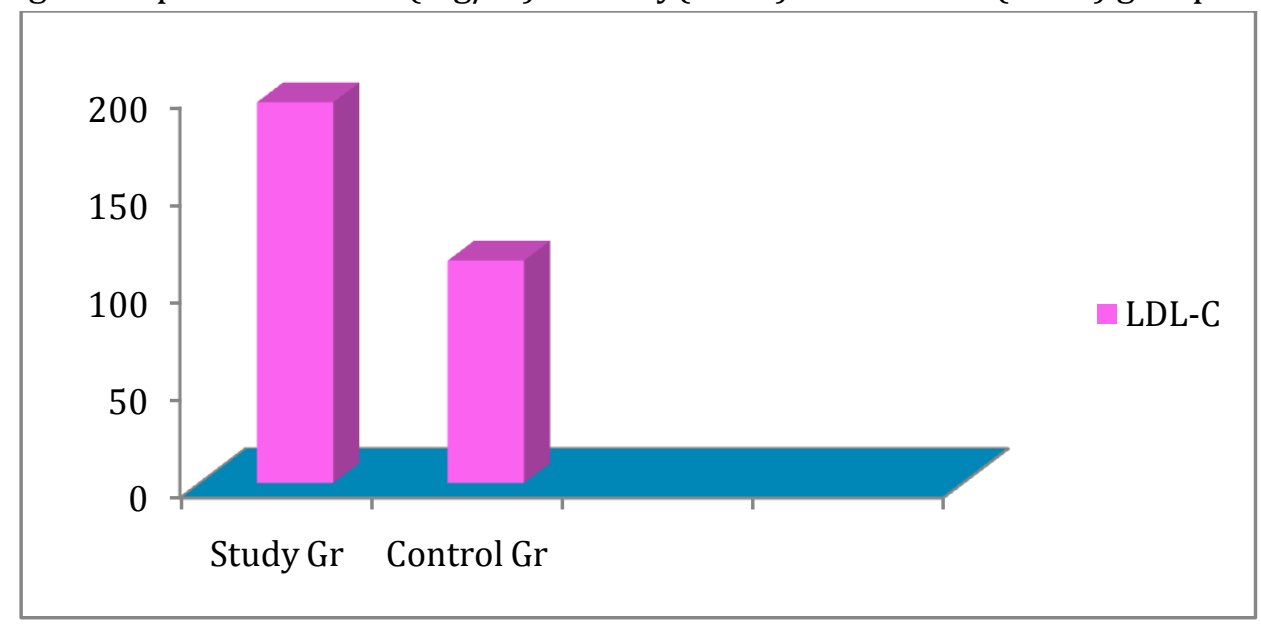


Figure:7 Diagram represents Fasting blood sugar $(\mathrm{mg} / \mathrm{dl})$ in study(n=42) and control $(\mathrm{n}=37)$ group

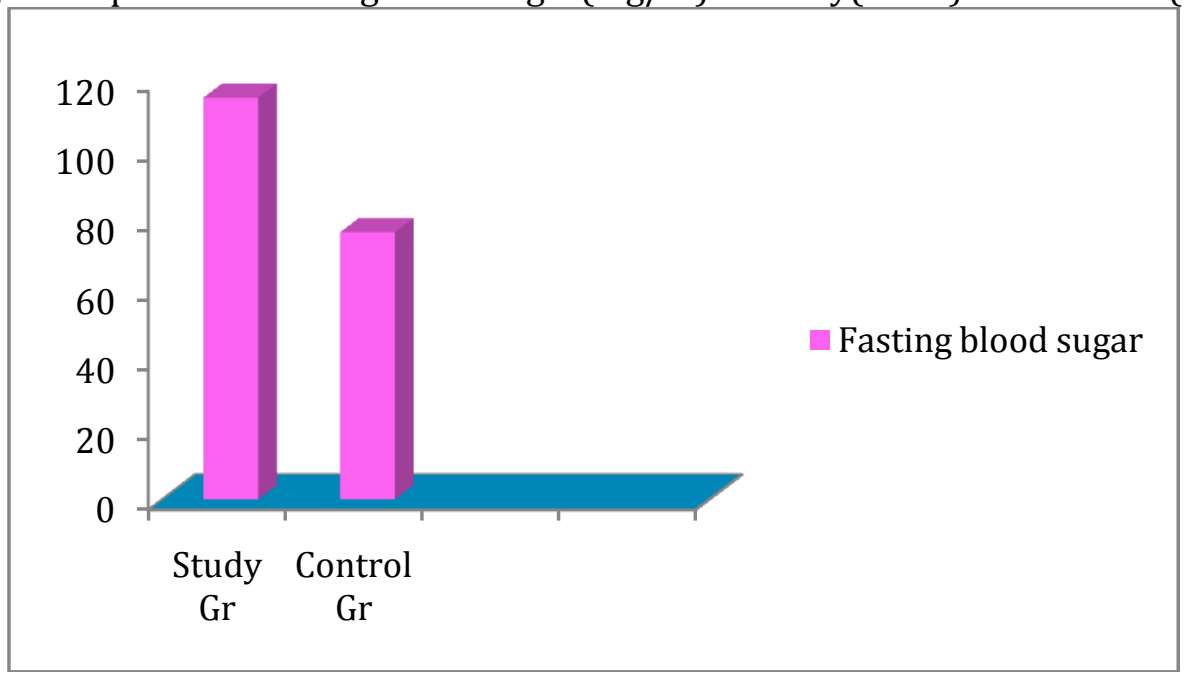

DISCUSSION: Coronary Heart diseases (CHD) is the most frequently found worldwide following hidden and untreated dyslipidemia with obesity and strong family history,smoking habit,junk/fast food intake in young age group between 25 to 45 years.The pathphysiological changes in obesity with dyslipidemia will eventually lead to CAD at an early age of life.

In our study it has been established that the mean of calculated BMI (weight in Kg / height in squaremeter) in study group $(n=42)$ is higher than control group.Table 3 shows the mean of BMI in study group is higher than control group. The results obtained was compared by Fisher's unpaired " $t$ test" where computed t-value is greater than the critical "t-value".BMI in study group is significantly higher than control group where the $\mathrm{p}$ value was $<0.001$.Figure 1 represents the significant elevation of BMI in study group compared with control group.The rise of BMI may be an earliest predictive non-invasive marker in study group.

In our study,total cholesterol,triglyceride,LDL-C are significantly higher in study group compared to control group. In obesity the peripheral utilization of sugar is impaired following low plasma and tissue concentration of insulin and as a result there is increased lipolysis and decreased re-esterification takes place which increases plasma free fatty acids. The activity of lipoprotein lipase is becoming low in obese, consequently the plasma level of VLDL-C,LDL-C,Triglyceride are increased(10,11).The HDL-C in study group is decreased significantly (Figure 4)as compared with control group and the $\mathrm{p}$ value was $<0.001$

CONCLUSION: This has been established that the measurement of BMI along with estimation of lipid profile and fasting blood sugar at least once in a year for young obese non-vegeterian, regular junk food eaters may prevent CHD by suitable preventive treatment at the earliest.

\section{REFERENCES:}

1. Lopez AD. Assessing the burden of mortality from cardiovascular disease. World Health Stat Q. 1993;46:91-96.

2. Murray CJL, Lopez AD. Global Comparative Assessments in the Health Sector. Geneva, Switzerland: World Health Organization; 1994. 
3. Thom TJ, Epstein FH, Feldman JJ, Leaverton PE, Wolz M. Total Mortality and Mortality From Heart Disease, Cancer, and Stroke From 1950 to 1987 in 27 Countries: Highlights of Trends and Their Interrelationships Among Causes of Death. Washington, DC: US DHHS PHS, National Institutes of Health; NIH publication No. 92-3088, 1992.

4. Whelton PK, Brancati FL, Appel LJ, Klag MJ. The challenge of hypertension and atherosclerotic cardiovascular disease in economically developing countries. High Blood Press. 1995;4:3645.

5. Feinleib M, Ingster L, Rosenberg H, Maurer J, Singh G, Kochanek K. Time trends, cohort effects and geographic patterns in stroke mortality: United States. Ann Epidemiol. 1993;3:458-465. Medline

6. Pearson TA, Jamison DT, Tergo-Gauderies J. Cardiovascular disease. In: Jamison DT, Mosley WH, eds. Disease Control Priorities in Developing Countries. New York, NY: Oxford University Press; 1993.

7. Omran AR. The epidemiologic transition: a key of the epidemiology of population change. Milibank Memorial Fund Q. 1971;49:509-538.

8. World Bank. World Development Report: Investing in Health. New York, NY: Oxford University Press; 1993.

9. Reddy KS. Cardiovascular disease in India. World Health Stat Q. 1993;46:101-107. Medline

10. Yao $\mathrm{C}, \mathrm{Wu} \mathrm{Z}, \mathrm{Wu}$ J. The changing pattern of cardiovascular diseases in China. World Health Stat Q. 1993;46:113-118.

Medline

11. Peto R. Tobacco: the growing epidemic in China. JAMA. 1996;275:1683-1684. CrossRefMedline

12. Peto R, Lopez AD, Boreham J, Thun M, Heath C Jr, Doll R. Mortality from smoking worldwide. Br Med Bull. 1996;52:12-21. Abstract/FREE Full Text

13. Drewnowski A, Popkin BM. The nutrition transition: new trends in the global diet. Nutr Rev. 1997;55:31-43.

Medline

14. Lang T. The public health impact of globalisation of food trade. In: Shetty PS, McPherson K, eds. Diet, Nutrition and Chronic Disease: Lessons From Contrasting Worlds. Chichester, UK: Wiley; 1997:173-187.

15. WHO: Obesity: Preventing and managing the global epidemic. Report of a WHO consultation. Geneva,WHO Technical Report Series 894, 2000.

16. Banegas JR, López-García E, Gutiérrez-Fisac JL, Guallar-Castillón P, Rodríguez-Artalejo F: A simple estimate of mortality attributable to excess weight in the European Union. Eur J Clin Nutr 2003;57:201-8.

17. James WP: The epidemiology of obesity: the size of the problem. J Intern Med 2008;263:33652

18. Yanovski SZ, Yanovski JA. Obesity. N Engl J Med 2002;21;346:591-602.

19. Haslam DW, James WP: Obesity. Lancet 2005;366:1197-2 


\section{ORGINAL ARTICLE}

20. Branca F, Nikogosian H, Lobstein T (eds): Th challenge of Obesity in the WHO European Region and the Strategies for Response: Summary Copenhagen, WHO Regional Office for Europe, 2007.

21. Larsen, Joeanne; MS, RD, LD http://www.dietitian.com/junkfood.html

22. Johnson, Paul M.; Kenny, Paul J. (2010). "Addiction-like reward dysfunction and compulsive eating in obese rats: Role for dopamine D2 receptors". Nature Neuroscience 13 (5): 635-41.

23. Goodwin, Jenifer. Junk Food 'Addiction' May Be Real. Business Week. March 29, 2010.

24. The children are also more prone to type 2 diabetes, raised cholesterol, and high blood fat. http://www.cbsnews.com/stories/2008/07/01/health/webmd/main4222324.shtml "Moms Eat Junk Food, Kids Get Fat". CBS News. 2008-01-06. Retrieved 2011-04-04

25. http://www.wordnetweb.princeton.edu/perl/webwndead link

26. http://www.diet.com/g/glossary

27. http://www.google.com/search?hl=en\&safe=off\&client=firefox a\&hs=blB\&rls=org.mozilla:enUS:official\&q=junk+food\&tbs=dfn:1\&tbo=u\&sa=X\&ei=VLQgToj7 KObf0QGfpPTJAw\&ved=0CEsQkQ4\%7C

28. O'Neill, Brendon (November 30, 2006). "Is this what you call junk food?". BBC News. Retrieved June 29, 2010.

29. Larsen, Joeanne; MS, RD, LD http://www.dietitian.com/junkfood.html

30. http://www.huffingtonpost.com/linda-larrowe-bergersen/what-makes-a-foodijunki_b_663571.html

31. http://www.wisegeek.com/what-is-junk-food.htm

32. http://www.webmd.com/diet/features/junk-food-facts 